\title{
Mihály Biró's Sarcastic Report on the Third Demonstrative Exhibition of Ma (1918)
}

\section{András Kappanyos}

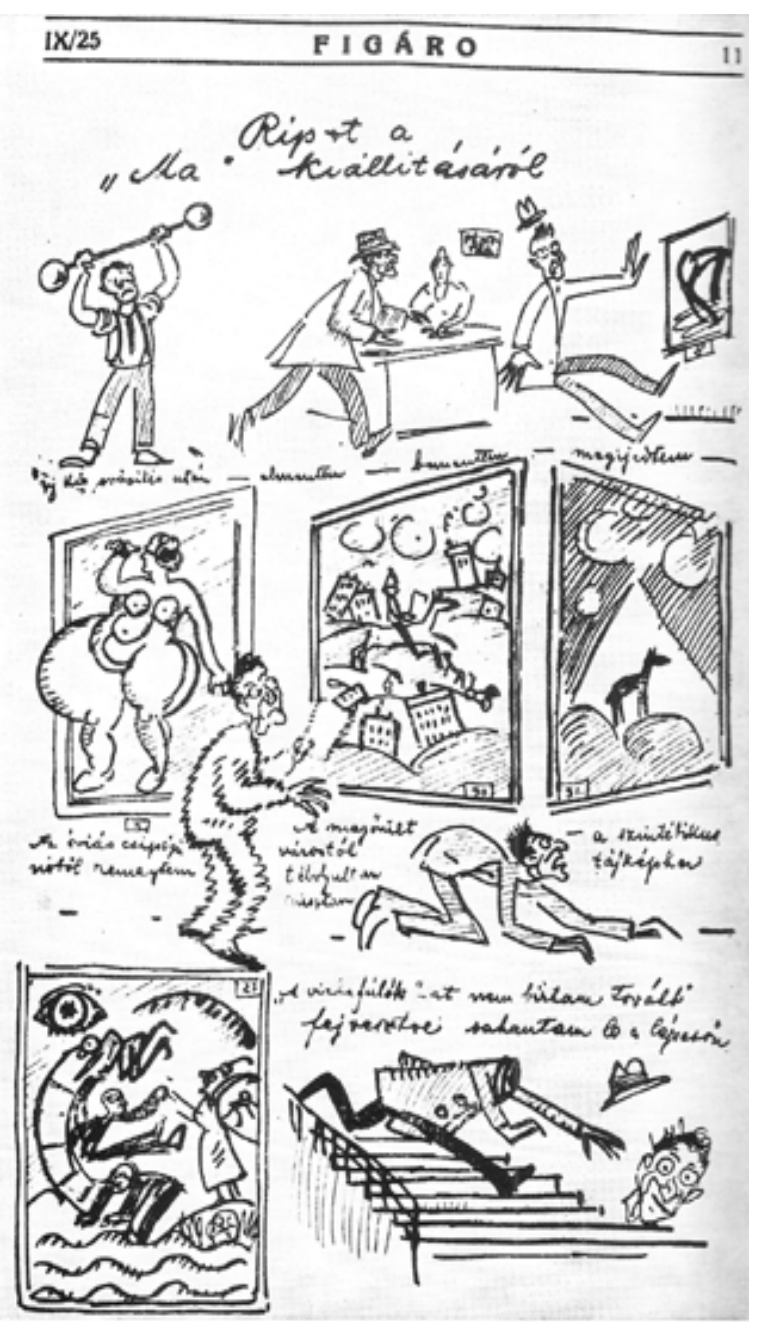

Report on the "Ma" exhibition

After some workout - I went there - I entered - I got scared -

I was terrified of the wide-hipped woman - I crept away from the "City Gone Mad" - to the "Synthetic Landscape"

At the "Drowning People" I couldn't bear it any more. With my head lost I ran down the stairs

Lajos Kassák (1887-1967), father figure of the Hungarian avant-garde and a sympathizer of Futurism, had been editing his periodicals $A$ Tett (The Action) and $M a$ (Today) for two years in his mother's small flat. In 1917, he rented a relatively spacious mezzanine flat at 15 Visegrádi Street, at the edge of downtown Pest, near the industrial district. For while, this 
place served as family home, headquarters of the Activist movement, editorial office and exhibition space. After two one-man shows Kassák organized in autumn 1918 a collective exhibition which he called 'demonstrative'. He wanted to present his movement as a wide spectrum of cultural forces that contains poets, writers of fiction, critics, visual artists, musicians, performers. Although their financial sources were very limited, Kassák wanted to impress the public and 'demonstrate' that they had a full infrastructure (for printing, publishing, staging, exhibiting, etc.) behind them.

"The Third Demonstrative Exhibition" of Ma took place from 15 September to 15 October1918. The catalogue was published by $M a$ on 15 September 1918, together with Kassák's opening speech ${ }^{1}$ and used the exhibition poster for its cover. The catalogue contains 53 items (paintings, prints, sculptures) by 13 artists. The Ma group also used the occasion to promote their books and brochures, as well as foreign avant-garde periodicals. According to Kassák, the enterprise was a great success, despite the political turbulences of the time. ${ }^{2}$

The short-lived periodical Figáró was a weekly cultural magazine with the subtitle 'Színház, müvészet, irodalom, divat, sport' (Theatre, Art, Literature, Fashion, Sport) and a satirical bend. Mihály Biró (1886-1948) was a painter and graphic artist of Jewish origin, who lived for a while in Germany, Austria and England and moved to America during the Nazi period. His best known work, A kalapácsos vörös ember (The Red Man with the Hammer, 1912) shows a muscular worker in the nude who threateningly rises his sledgehammer, was originally drawn in 1911 as a poster for Népszava, the newspaper of the Social Democrats' Party (its publisher was Dezső Biró, elder brother of the artist). This image became the most important visual symbol of the Party, and remained in constant use up until the forced union with the Communists in 1948. In 1919, during the short-lived Hungarian Soviet Republic, he was responsible for the visual design of the May Day celebrations. Together with other members of the Ma group, especially Béla Uitz and Róbert Berény, he was responsible for the best part of the revolutionary posters issued in Hungary in 1918-19.

Biró's caricatures of artistic and social events often used first-person narratives, which can also be found in his full-page pictorial report on the $M a$ exhibition, published in the second issue of Figáró. The criticism and satire has little political component and is merely aesthetic.

\footnotetext{
${ }^{1}$ Kassák: "A 'Ma' demonstratív kiállításához", p. 90.

${ }^{2}$ Kassák: Egy ember élete. Vol. 2, p. 415.
} 
The peculiarity of this cartoon is that instead of mocking a trend or some mannerisms it pokes fun at specific works of art that can be identified from the catalogue. Biró includes the caricatures of five particular pictures the protagonist encounters in the Ma exhibition and he even emphasizes this specificity by presenting their catalogue numbers.

The first picture is No. 8, a painting by János Máttis Teutsch (1884-1960), entitled Drama. I was unable to identify the original painting with this title, but we can be certain that it was one of several narrow-angle landscapes that Mattis Teutsch produced at the time. ${ }^{3}$ They usually depict a small hill, lined with roads or fences, with a group of trees leaning together or bending in the wind. The patches of colour are very bright, dramatic and mostly warm, showing a Fauvist influence, while the drawing of the lines is rather bold, resembling the floral meandering of Art Nouveau. In his black and white caricature, Biró concentrates on the lines, but the mockery concerns the general arbitrariness, the assumed 'nonchalance' of Teutsch's technique. The essence of his criticism of the painting is the mere fact that it did not take him more than two seconds to 'represent' it.

The second picture (No. 1 in the catalogue) is a rather conventional female nude by János Kmetty (1889-1975). With its sharp contrasts of light and shade it shows a body as if it had been assembled from flat surfaces. The painting clearly shows some Cubist influence while the strong sensation of visual depth and mass hint at Cézanne. However, these elements are neglected by Biró: he concentrates only on the features of the full-bodied (one would say 'Rubenesque') model, which he exaggerates greatly, drawing her with hips expanding beyond the picture frame.

The other three caricatured pictures (Nos. 31, 31 and 27) belong to Sándor Bortnyik (1893-1976), who was one of the youngest participants in the exhibition. After his early Symbolist period, he came into contact with the Kassák circle and turned toward CuboFuturism. His pictures are often divided, at least partially, by distinct polygons that serve as elements of a stage setting as well as thematic 'borders' between simultaneous scenes of a picture's narrative. His paintings seem to be even more unusual for Biró than the other two (or the further items of the exhibition) and are more difficult to mock. They are clearly figurative; they represent some identifiable element of reality, but in a grotesque, somewhat

\footnotetext{
${ }^{3}$ A very likely candidate is the landscape that was used as poster and catalogue front piece for the exhibition, Allegro Barbaro: Béla Bartók et la modernité hongroise 1905-1920 at the Musée d'Orsay in 2013-14.
} 
mocking way. Also, the divided surface itself is reminiscent of the narrative methods of a cartoon. Biró, in fact, offers in his representations hardly more than draft sketches in his own style. This is rather fortunate as the originals of these three pictures are now considered lost. ${ }^{4}$ Biró, nevertheless, makes a point of distancing himself from Bortnyik, which is why he changed the original title Város (City) to Megörült város (City Gone Mad). The other two titles, Vizbefúlók and Szintétikus tájkép ("Drowning People" and "Synthetic Landscape"), might have seemed 'mad enough' in themselves.

Biró's narrative tells a story of escalating madness, but he cannot really put his finger on the imputed madness of Bortnyik's paintings. So he illustrates it by using the allegory of the woman's hip that protrudes from the picture frame: here the madness also leaves the surface of the pictures; it invades the mind of the onlooker, who, besides going mad himself, becomes similar to these strange pictures and literally 'loses his head'.

\section{Bibliography}

Barki, Gergely, ed.: Allegro Barbaro: Béla Bartók et la modernité hongroise 1905-1920. Exhibition catalogue. Paris: Musée d'Orsay, 15 octobre 2013 - 5 janvier 2014. Paris: Hazan, 2013.

Biró, Mihály: "Riport a 'Ma' kiállításáról." Figáró 1:2 (25 September 1918): 11.

Borbély, László: Bortnyik. Budapest, Corvina, 1971.

Kassák, Lajos: "A 'Ma' demonstratív kiállitásához." Ma 3:8-9 (15 September 1918): 90.

--: Egy ember élete. Budapest: Magvető, 1983.

Ma 3:8-9 (15 September 1918): 107. A "Ma" (III) demonstratív kiállításának katalógusa

Noever, Peter, ed.: Mihály Biró: Pathos in Rot = Mihály Biró: Pathos in Red. Wien: MAK, 6.10.2010 -

9.1.2011. Nürnberg: Verlag für Moderne Kunst, 2010.

\footnotetext{
${ }^{4}$ See Borbély: Bortnyik, p. 6.
} 